International Review of Research in Open and Distributed Learning Volume 22, Number 1

February - 2021

\title{
The Impact of Demographic Characteristics on Academic Performance: Face-to-Face Learning Versus Distance Learning Implemented to Prevent the Spread of COVID-
}

\section{9}

Ghaleb A. El Refae ${ }^{1}$, Abdoulaye Kaba ${ }^{2}$, and Shorouq Eletter ${ }^{1}$

${ }^{1}$ College of Business, Al Ain University, Al Ain, United Arab Emirates, ${ }^{2}$ College of Education, Humanities and Social Sciences, Al Ain University, Al Ain, United Arab Emirates

\begin{abstract}
The spread of COVID-19 presents an opportunity for many educational institutions to implement distance learning and ensure the provision of educational resources and services, secure income and revenues, and contribute to the control and prevention of the coronavirus. This study was conducted to investigate the impact of demographic characteristics on academic performance. Students' grades and grade point averages (GPA) were collected from the Admission and Registration Unit, Al Ain University in Al Ain, United Arab Emirates. The data were used to measure academic performance in face-to-face (F2F) learning and distance learning (DL) implemented by the university to prevent the spread of COVID-19. Statistical analysis including the Mann-Whitney test, Spearman's rho test, and a regression test were used to answer research questions and verify hypotheses. Students demonstrated better academic performance in DL than F2F learning. It was found that the number of weak students in F2F learning dropped sharply by more than $11 \%$ in DL. Demographic characteristics demonstrated a significant impact on students' academic performance and predicted at least 7.4\% variation in F2F learning and DL. Findings of the study support the model developed by Tinto (1975) which proposed the impact of student's attributes, experiences, and family backgrounds on academic performance. The findings suggest non-DL institutions should continue offering DL side-by-side with F2F learning programs.
\end{abstract}

Keywords: demographic characteristics, academic performance, face-to-face learning, distance learning, coronavirus, COVID-19 


\section{Introduction}

Educational institutions can be categorized as distance learning (DL), blended learning, or traditional or face-to-face (F2F) learning institutions. At DL institutions, learning takes place without physical presence (Cheawjindakarn et al., 2012), while blended or hybrid learning institutions combine traditional classroom teaching with educational technologies (Kamalluarifin et al., 2018). Traditional learning institutions rely on learning activities and instruction in the classroom without the use of online learning and instructions (Elfaki et al., 2019).

Regardless of the types of educational institutions, the spread of COVID-19 is presenting opportunities and challenges for all types of academic institutions. For DL institutions, the business is as usual, with more opportunities and limited challenges. For blended learning institutions, the pandemic is an opportunity to improve DL tools and equipment, facilities and infrastructures, marketing strategies, and planning. However, for traditional learning institutions, the implementation of DL has been very challenging.

Like many other Gulf countries, the United Arab Emirates (UAE) decided from the beginning of the pandemic to implement DL as an alternative to traditional teaching. The decision was taken in the first week of March 2020 and required all educational institutions to close for four weeks, make necessary arrangements, and complete the academic year through DL. Accordingly, schools and higher academic institutions started delivering courses through DL in the last week of March 2020 (United Arab Emirates, The Ministry of Education, 2020; United Arab Emirates' Government Portal, 2020). It is interesting to note that although Hamdan Bin Mohammed Smart University was the first accredited DL institution in the UAE, other academic institutions have been fully or partially implementing DL since before the spread of the coronavirus, including Al Ain University (Ati \& Guessoum, 2010; Lavine \& Croome, 2018).

$\mathrm{Al}$ Ain University (AAU) is licensed as F2F high education institution in UAE despite using many platforms and tools required for DL before the COVID-19 pandemic. These include Edu-Gate, Moodle, MS Teams, online registration, and a digital library. In fact, before the coronavirus outbreak, the university had been conducting online examinations for some courses every semester according to the examination timetables posted by the Admission and Registration Unit. The availability of these tools, services, and experiences is the key success factor in implementing DL for the first time in all courses offered during the second semester of the academic year 2019-2020.

Irrespective of learning styles and types of educational institutions, students' academic performance can be influenced by a variety of factors such as demographic characteristics, learning environment, employment, and income. Prior studies have compared F2F learning to DL and explored the impact of demographic characteristics on academic performance (Zhao \& Abuizam, 2015; Alghamdi et al., 2020). However, these studies were conducted before the spread of COVID-19 and mostly in Western countries (Bernard et al., 2004; Shachar \& Neumann, 2010; Nortvig et al., 2018).

This study is an attempt to determine the impact of demographic characteristics on academic performance. According to Tinto (1975), demographic characteristics such as gender, level of study, and specialization play an important role in determining students' academic performance, and this has been proven by many empirical studies (Ortega-Maldonado et al., 2017; Brubacher \& Silinda, 2019). This study also compares 
academic performance in $\mathrm{F} 2 \mathrm{~F}$ learning with DL implemented for the first time by AAU to prevent the spread of COVID-19. It is the first study comparing F2F learning to DL at AAU. The results may be useful in understanding the impact of gender, college, and status of students on academic performance, and may be important in dealing with factors affecting academic performance. The study contributes to understanding F2F learning and DL in the Arab world as well as the impact of COVID-19 on academic institutions.

\section{Review of Related Studies}

A review of research on students' academic performance in F2F learning and DL shows mixed results. In some studies, F2F outperformed DL (Ferguson \& Tryjankowski, 2009; Christmann, 2017), while in others, DL outperformed F2F (Duffy et al., 2002; Elfaki et al., 2019). Additionally, there are studies that report no significant difference in students' academic performance in DL as compared to F2F learning (Jahng et al., 2007; Smith, 2013; Paul \& Jefferson, 2019).

Bernard et al. (2004) conducted a comprehensive meta-analysis of literature, reviewing 232 empirical studies related to DL and F2F learning. The authors identified the significant impacts of teaching methodology, pedagogy, and media on students' academic performance in both F2F learning and DL. Students' academic performances were better when efficient delivery or cost was a reason for offering DL. Similar results were reported for students specializing in military and business studies. However, no differences were found between undergraduate and postsecondary education. Nevertheless, graduate schools demonstrated significant results in favor of DL as compared to F2F learning.

In another comprehensive meta-analysis, Shachar and Neumann (2010) reviewed 125 studies published over twenty years (1990-2009) to identify differences in the academic performance of students in DL and F2F learning. The findings of their study indicate a significant difference in the final grades of students enrolled in DL and F2F learning. Besides, the authors identified changes observed across time and directional patterns. The ratio of positive effect sizes across time improved steadily from $63 \%$ up to $84 \%$. According to them, students' academic performance in DL was not only comparable to F2F learning but even outperformed it.

In a recent review study, Nortvig et al. (2018) identified factors affecting students' academic performance in DL and blended learning. The dominant factors included the presence of an instructor, interactions, content, and connections between online and offline as well as practice-related activities. The three comprehensive review studies discussed above show that the literature comparing students' academic performance in F2F learning and DL is extensive.

As pointed out by Ismail et al. (2018), students' characteristics including gender, age, status, and ethnicity are among the most significant factors influencing academic performance (Urtel, 2008; Tamim et al., 2011). In the United States, Urtel (2008) explored differences in student academic performance in F2F and DL. The author used grades of 385 students as an indicator of academic performance. The findings revealed a significant difference in academic performance connected to gender, student status, and ethnicity. To be 
more specific, female students in F2F learning outperformed female students in DL, but freshmen students of all genders underperformed when compared to other students.

In a separate study, Christmann (2017) compared the academic performance of students enrolled in a statistics course that was offered through DL and F2F learning. Results of the study found that female students in DL outperformed male students, while male students in the F2F learning section scored higher than females. In examining the role of gender and student performance in DL and F2F learning classes, Amparo et al. (2018) used GPA indicators to explore gender differences. Findings of that study showed that female students outperformed male students in F2F classes, while male students and female students demonstrated equal performance in DL.

Similar studies have reported the impact of individual motivation, learning strategies, and cognitive ability on academic performance (Logan et al., 2017; Stark, 2019). Likewise, others have explored differences and similarities between F2F learning and DL with respect to demographic characteristics, satisfaction, competences, learning outcomes, and academic performance (Ortega-Maldonado et al., 2017; Brubacher \& Silinda, 2019). An interesting investigation by Fadda (2019) identified goal orientation, self-efficacy, time and study environment management, seeking assistance, and Internet self-efficacy as self-regulatory attributes that predict academic performance.

The review of literature shows sufficient studies that have investigated academic performance in F2F learning and DL. Prior studies have explored students' differences in F2F learning and DL as well as other factors affecting academic performance. The factors included demographic characteristics, attitude and perception, competencies, and skills. The current study reports students' academic performance in F2F learning and DL implemented to prevent the spread of the coronavirus. Findings of this study should contribute to the understanding of the impact of COVID-19 on students' academic performance.

\section{Conceptual Background}

\section{Demographic Characteristics}

Demographic characteristics refer to attributes that describe the status of people or a person such as age, gender, ethnicity, or income. This study used gender, college, and status of students as demographic characteristics. Gender denotes biological differences in being male or female. College in this study refers to the schools or faculty of AAU. It consists of two groups: (a) English-based instruction colleges, which include engineering, pharmacy, and business, and (b) Arabic-based instruction colleges, which include law, education, and communication. Status refers to whether a student is a junior or a senior. We consider firstand second-year students as junior, while third-, fourth-, and fifth-year students are considered senior. Prior studies have suggested that demographic characteristics such as these can have an impact on academic performance (Christmann, 2017; Amparo et al., 2018). 


\section{Face-to-Face Learning}

$\mathrm{F} 2 \mathrm{~F}$ or traditional learning is a style of learning in which a teacher or instructor meets in person with students in a physical classroom at a specific time. In F2F learning, activities and instruction occur in the classroom without the use of online tools (D'Abundo \& Sidman, 2018). This style allows learners to have direct and physical interaction with instructors and fellow students, ensures better understanding of lesson content, and gives class members a chance to work together (Amro et al., 2015).

\section{Distance Learning}

Distance learning, distance education, e-learning, online learning, computer-mediated learning, and Webbased learning refer to a process that takes place without physical presence. Unlike F2F learning, activities and instructions in DL occur through the use of learning technologies. F2F learning and DL have been explored by many researchers (Bernard et al., 2004; Shachar \& Neumann, 2010; Nortvig et al., 2018).

\section{Conceptual Framework}

Figure 1 illustrates the conceptual framework of the study. The framework consists of three independent and two dependent variables. The independent variables are gender, college, and status of the student, while dependent variables are academic performance in $\mathrm{F} 2 \mathrm{~F}$ learning $(\mathrm{AP}-\mathrm{F} 2 \mathrm{~F})$ and academic performance in $\mathrm{DL}$ (AP-DL). The framework assumes the impact of demographic characteristics or independent variables on academic performance or dependent variables. This conceptual assumption is supported by a theoretical model proposed by Tinto (1975). According to his model, students who attend higher education possess a variety of attributes, experiences, and family backgrounds that may have a direct and indirect impact on their academic performance (Christmann, 2017; Amparo et al., 2018). Prior studies have used the model to identify the relationship between demographic characteristics and academic performance (Ibrahim et al., 2007; Amro et al., 2015). Accordingly, we found the model applied to the current topic.

\section{Figure 1}

\section{The Proposed Conceptual Framework}

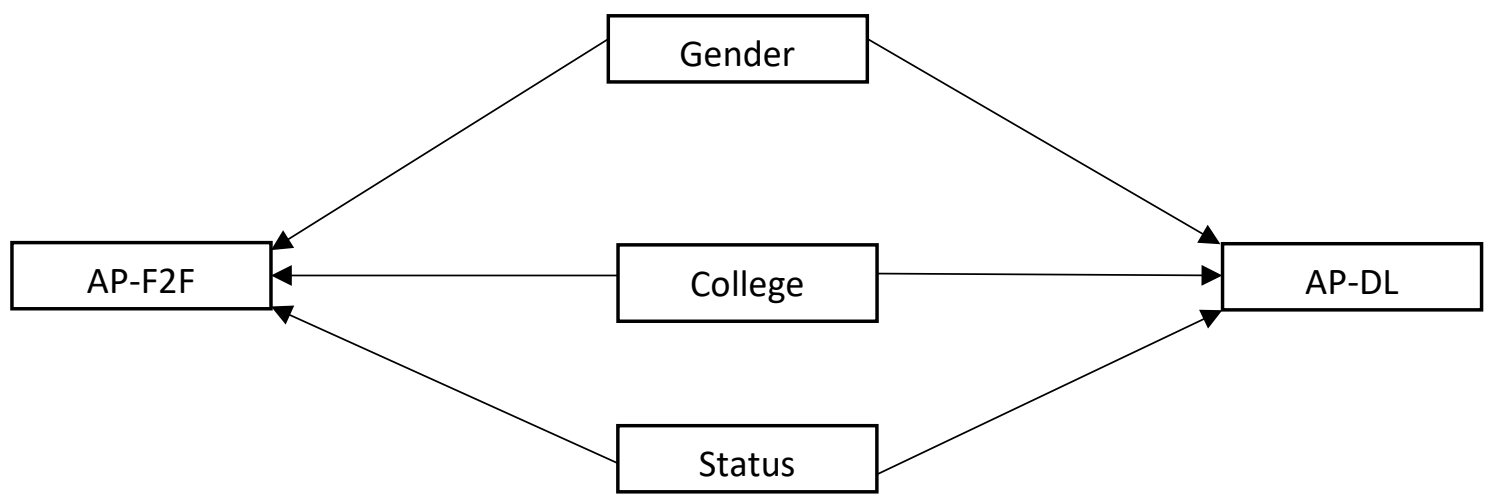


Note $\mathrm{AP}=$ academic performance; $\mathrm{F} 2 \mathrm{~F}=$ face-to-face learning; $\mathrm{DL}=$ distance learning.

\section{Research Questions and Hypotheses}

In light of the conceptual framework, the theoretical model proposed by Tinto (1975), and previous studies (Al-Mously et al., 2013;), we asked six research questions and proposed six hypotheses.

\section{Research Questions}

1. Does gender have an impact on academic performance in F2F learning?

2. Does a college have an impact on academic performance in F2F learning?

3. Does status have an impact on academic performance in F2F learning?

4. Does gender have an impact on academic performance in DL?

5. Does a college have an impact on academic performance in DL?

6. Does status have an impact on academic performance in DL?

\section{Research Hypotheses}

1. Gender is related to academic performance in F2F learning.

2. College is related to academic performance in F2F learning.

3. Status is related to academic performance in F2F learning.

4. Gender is related to academic performance in DL.

5. College is related to academic performance in DL.

6. Status is related to academic performance in DL.

\section{Research Method}

\section{Study Population}

The main objective of this study is to investigate the impact of demographic characteristics on academic performance. It uses students' grades and grade point averages (GPA) as indicators of academic performance in F2F learning and DL implemented to prevent the spread of COVID-19. As illustrated in Table 1, the population of the study are students enrolled in various courses offered by AAU as F2F in the first semester and DL in the second semester for the academic year 2019-2020. 


\section{Table 1}

Sociodemographic Characteristics of Participants

\begin{tabular}{|c|c|c|}
\hline Characteristic & $n$ & $\%$ \\
\hline \multicolumn{3}{|l|}{ Gender } \\
\hline Male & 294 & 49.7 \\
\hline Female & 297 & 50.3 \\
\hline \multicolumn{3}{|l|}{ College } \\
\hline English-based instruction a & 290 & 49.1 \\
\hline Arabic-based instruction ${ }^{b}$ & 301 & 50.9 \\
\hline \multicolumn{3}{|l|}{ Status } \\
\hline Junior c & 280 & 47.4 \\
\hline Senior d & 311 & 52.6 \\
\hline
\end{tabular}

Note. $N=591$.

a Engineering, pharmacy, and business. ${ }^{\mathrm{b}}$ Law, education, and communication. ${ }^{\mathrm{c}} 1^{\text {st }}$ and $2^{\text {nd }}$ year. ${ }^{\mathrm{d}} 3^{\text {rd }}$ to $5^{\text {th }}$ year.

\section{Data Collection}

Approval from a relevant AAU authority allowed researchers to collect data from the Admission and Registration Unit in June 2020. Based on the scope of the study, we collected two categories of data.

As presented in Table 2, the first category of data is based on 5,198 students' grades (i.e., A, B+, B, etc.) reported in F2F learning and DL courses during the first and second semesters for the academic year 20192020. The second category of data is based on 591 students' semester grade point averages (SGPA) and overall grade point averages (GPA) as reported in F2F learning and DL courses during the same semesters.

Table 2

Types of Collected Data

\begin{tabular}{|c|c|c|c|}
\hline Category & Data & Number of students & Learning style \\
Grade & A, B+, B, C+, C, D+, D & & F2F \\
& & 5,198 & DL \\
SGPA & $0.00-4.00$ & & F2F \\
& & 591 & DL \\
GPA & $0.00-4.00$ & 591 & F2F \\
& & & DL
\end{tabular}

Note. $\mathrm{SGPA}=$ semester grade point average; $\mathrm{GPA}=$ grade point average; $\mathrm{F} 2 \mathrm{~F}=$ face to face learning; $\mathrm{DL}=$ distance learning.

Currently, AAU consists of six colleges. However, for statistical analysis, we decided to split the six colleges into two groups: (a) English-language colleges and (b) Arabic colleges. The first group consists of the colleges of Engineering, Pharmacy, and Business, while the second group consists of the colleges of Law, 
Education, and Communication. Similarly, for the purposes of the research, we categorized the students as junior or senior. First- and second-year students are considered junior, while the third-, fourth-, and fifthyear students are senior in this study.

\section{Data Treatment}

The researchers coded and analyzed the collected data through IBM SPSS Statistics (Version 26). Because of the nature of the collected data, i.e., grade, SGPA, and GPA, validity and reliability tests, as well as factor analysis, were not required in this study. Frequency distributions, percentages, and statistical analysis were performed, analyzed, and interpreted to find answers to the research questions, and also to verify and validate the research hypotheses.

\section{Findings}

\section{Grades in F2F Learning and DL}

Our first analysis concerns students' grades. The reported grades shown in Table 3 are for 5,198 students from six colleges, registered in various courses of bachelor's, diploma, and master's programs, in semesters one and two of the academic year 2019-2020. The first semester was conducted through F2F learning while the second semester was delivered through DL to prevent the spread of the coronavirus. The table summarizes the differences between F2F learning and DL with respect to students' grades. Similarly, Figure 2 compares the academic performance of BA students with MA and diploma students in F2F learning and DL. 


\section{Table 3}

Mann-Whitney Test for the Difference Between F2F Learning and DL in Students' Grades

$\begin{array}{cccccc}\text { Grade } & \text { Teaching method } & \text { Total } & \text { Mean rank } & \text { Z-value } & p \text {-value } \\ \text { A } & \text { F2F } & 2909 & 11.55 & -0.003 & 0.974 \\ \text { B }+ & 2622 & 11.45 & & \\ & \text { F2 } & 2903 & 11.14 & & 0.793 \\ \text { B } & \text { DL } & 3187 & 11.86 & -0.263 & \\ & \text { F2F } & 3384 & 11.09 & -0.296 & 0.768 \\ \text { C+ } & \text { DL } & 3960 & 11.91 & & \\ & \text { F2F } & 3648 & 11.41 & & 0.947 \\ \text { C } & \text { DL } & 3887 & 11.59 & -0.066 & \\ & \text { F2F } & 3275 & 12.64 & & 0.409 \\ & \text { DL } & 1803 & 10.36 & -0.825 & \\ \text { D+ } & \text { F2F } & 1299 & 13.00 & & 0.262 \\ & \text { DL } & 475 & 10.00 & -1.122 & \\ & \text { F2F } & 1132 & 12.91 & & \\ & \text { DL } & 405 & 10.09 & -1.054 & 0.292\end{array}$

Note. $\mathrm{F} 2 \mathrm{~F}$ = face-to-face learning; $\mathrm{DL}=$ distance learning.

\section{Figure 2}

Illustrates Additional Differences in Students' Academic Performances (Grades) in Respect to the Study Level

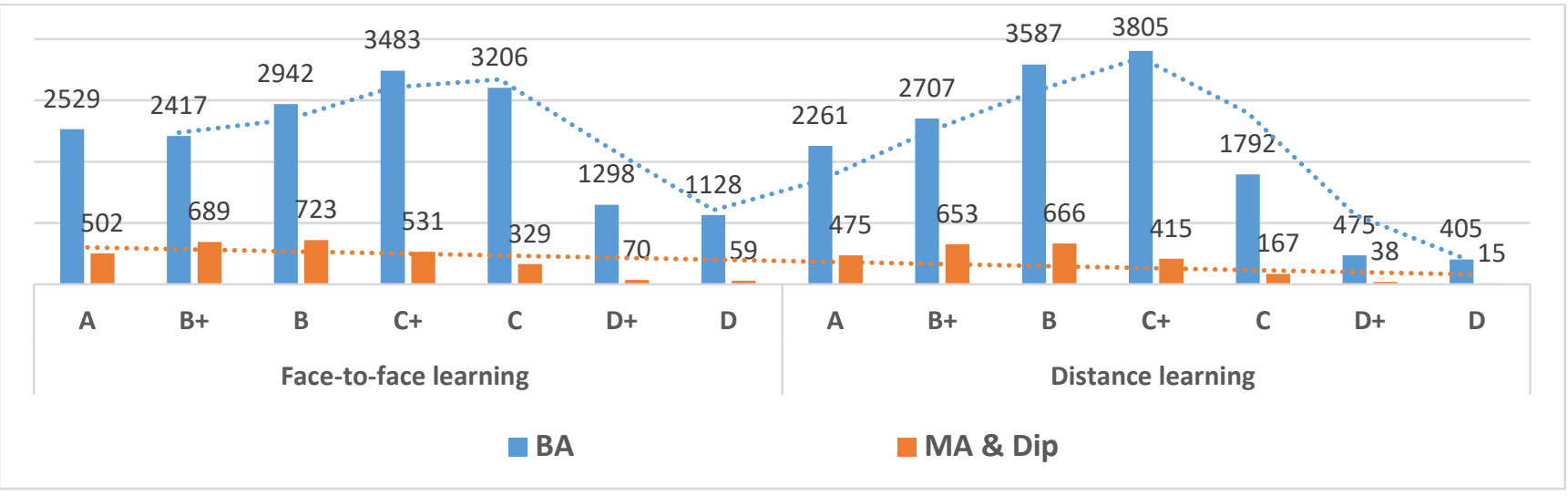




\section{GPAs in F2F Learning and DL}

The analysis in this section is based on a sample of 591 students selected randomly to compare semester grade point average (SGPA) against grade point average (GPA) in F2F learning and DL. As presented in Table 4 , the findings show that $49 \%$ of students achieved 3.0 to 4.0 SGPA in DL compared to $38 \%$ of students in F2F learning courses. Similarly, 34\% of students recorded a 3.0 to 4.0 GPA in DL compared to $31 \%$ of students in F2F learning. The number of students with less than 2.5 SGPA in F2F learning dropped sharply by $11 \%$ in DL. Likewise, the number of students with less than 2.5 GPA in F2F learning dropped slightly by $3 \%$ in DL.

\section{Table 4}

Students' GPAs in F2F Learning and DL

\begin{tabular}{|c|c|c|c|c|c|c|c|c|c|}
\hline \multirow{2}{*}{ SGPA } & \multicolumn{2}{|c|}{$\mathrm{F} 2 \mathrm{~F}$} & \multicolumn{2}{|c|}{$\mathrm{DL}$} & \multirow{2}{*}{ GPA } & \multicolumn{2}{|c|}{ F2F } & \multicolumn{2}{|c|}{$\mathrm{DL}$} \\
\hline & $N$ & $\%$ & $N$ & $\%$ & & $N$ & $\%$ & $N$ & $\%$ \\
\hline $3.6-4.0$ & 92 & 15.56 & 112 & 18.95 & $3.6-4.0$ & 79 & 13.36 & 78 & 13.19 \\
\hline $3.0-3.59$ & 133 & $22.5^{0}$ & 183 & 30.96 & $3.0-3.59$ & 109 & 18.44 & 126 & 21.31 \\
\hline $2.5-2.99$ & 126 & 21.31 & 122 & 20.64 & $2.5-2.99$ & 118 & 19.96 & 124 & 20.98 \\
\hline $2.0-2.49$ & 110 & 18.61 & 90 & 15.22 & $2.0-2.49$ & 170 & 28.76 & 166 & 28.08 \\
\hline$<2.0$ & 130 & 21.99 & 84 & 14.21 & $<2.0$ & 115 & 19.45 & 97 & 16.41 \\
\hline
\end{tabular}

Note. SGPA = semester grade point average; GPA = grade point average; F2F = face-to-face learning; DL

$=$ distance learning.

As presented in Table 5, students in DL demonstrated better academic performance in terms of SGPA (mean rank $=630.38$ ) and GPA (mean rank $=604.13$ ) than the students enrolled in F2F learning courses (SGPA mean rank $=552.62$, GPA mean rank $=578.78$ ). The differences in SGPA and GPA between the two learning styles are statistically significant $(Z$ value $=-3.917, p$-value $=0.00)$. The findings suggest a positive impact of DL on students' academic performance.

\section{Table 5}

Results of the Mann-Whitney Test

$\begin{array}{cc}\text { Learning style } & \text { Academic performance } \\ \text { F2F } & \text { SGPA } \\ \text { DL } & \\ \text { F2F } & \text { GPA } \\ \text { DL } & \end{array}$

$\begin{array}{ccc}\text { Mean rank } & \text { Z value } & p \text {-value } \\ 552.62 & & \\ 630.38 & -3.917 & 0.000^{*} \\ 578.87 & & \\ 604.13 & -1.273 & 0.203\end{array}$

Note. $N=591$.

* Significant at 0.05 (2-tailed).

\section{Demographic Characteristics and Academic Performance}

Table 6 summarizes the results of Spearman's rho correlation analysis applied to demographic characteristics and academic performance. This non-parametric test was preferred because an early normality test indicated that the data were not normally distributed. The demographic characteristics were 
gender, college, and status of students. The analysis of correlation indicates a positive significant relationship between gender and SGPA in F2F learning $\left(r_{s}=0.251\right)$ and DL $\left(r_{s}=0.253\right)$. Similarly, findings reveal a positive significant relationship between students' status and overall GPA in F2F learning $\left(r_{s}=\right.$ o.119) and DL $\left(r_{s}=0.117\right)$. Interestingly, the college variable indicates negative significant relationship with overall students' GPA in F2F learning $\left(r_{s}=-0.125\right)$ and DL $\left(r_{s}=-0.110\right)$. In addition, it has no significant relationship with SGPA in either F2F learning $\left(r_{s}=-0.038\right)$ or DL $\left(r_{s}=-0.060\right)$.

\section{Table 6}

Spearman's Rho Test Results Showing Correlation of Study Variables*

\begin{tabular}{lccccc}
\hline \multicolumn{1}{c}{ Variable } & 1 & 2 & 3 & 4 & 5 \\
\hline 1. Gender & - & & & & \\
2. College & $-.083^{*}$ & - & & & \\
3. Status & $.134^{* *}$ & -.050 & - & & \\
4. SGPA (F2F) & $.251^{* *}$ & -.038 & $.153^{* *}$ & - & \\
5. SGPA (DL) & $.243^{* *}$ & -.060 & $.198^{* *}$ & $.802^{* *}$ & - \\
6. GPA (F2F) & $.242^{* *}$ & $-.125^{* *}$ & $.119^{* *}$ & $.899^{* *}$ & $.796^{* *}$ \\
7. GPA (DL) & $.246^{* *}$ & $-.110^{* *}$ & $.117^{* *}$ & $.888^{* *}$ & $.877^{* *}$ \\
\hline
\end{tabular}

Based on the results of Spearman's correlation analysis which confirmed the relationship between students' academic performance and demographic characteristics, we performed a linear regression analysis to find out the impact of these variables on academic performance. The researchers assumed that gender, college, and status have a positive impact on a student's academic performance. The linear regression tests are based on the partial least squares structural equation modelling (PLS-SEM). Table 7 defines the symbols used in the models.

$$
\begin{aligned}
& \text { Model 1: } Y_{1}=\beta_{0}+\beta_{1} \text { Gender }+\beta_{2} \text { College }+\beta_{3} \text { Status }+\varepsilon \\
& \text { Model 2: } Y_{2}=\beta_{0}+\beta_{1} \text { Gender }+\beta_{2} \text { College }+\beta_{3} \text { Status }+\varepsilon
\end{aligned}
$$


Table 7

Definitions of Variables

\begin{tabular}{ll}
\hline \multicolumn{1}{c}{ Variable } & \multicolumn{1}{c}{ Definition } \\
\hline Y1 & academic performance in F2F learning \\
Gender & $=1$ if respondent is male, $\mathrm{O}$ if female \\
College & $=1$ if respondent is from English instruction college, $\mathrm{O}$ if Arabic \\
Status & $=1$ if respondent is junior, o if senior \\
$\varepsilon$ & errors \\
\hline
\end{tabular}

The models are based on the stated hypotheses. These hypotheses propose the impact of gender, college, and status of a student on academic performance in both F2F learning and DL. As presented in Table 8, findings of regression analyses indicate that gender, college, and status of student have positive and significant impact on students' academic performance in F2F learning $\left(R^{2}=0.075\right.$, adjusted $R^{2}=0.071, F$ $=15.929, p$-value $=0.000)$ and DL $\left(R^{2}=0.074\right.$, adjusted $R^{2}=0.070, F=15.737, p$-value $\left.=0.000\right)$. These results support the hypotheses and models of the study. Besides, the findings reveal that gender, college, and status of student explain at least $7.4 \%$ of the variation of students' academic performance in both F2F learning and DL. Although these results appear very weak, they indicate the existence of causation between demographic variables and academic performance.

\section{Table 8}

Demographic Characteristics and Academic Performance

\begin{tabular}{lcccc}
\hline \multirow{2}{*}{ Variable } & $\begin{array}{c}\text { Academic performance } \\
\text { F2F learning }\end{array}$ & \multicolumn{2}{c}{ in } & \multicolumn{2}{c}{ Academic performance in } \\
& \multicolumn{2}{c}{ Model 1 } & \multicolumn{2}{c}{ Model 2 } \\
& Coefficient & $p$-value & Coefficient & $p$-value \\
\hline Constant & 2.201 & 0.000 & 2.182 & 0.000 \\
Gender & 0.317 & 0.000 & 0.318 & 0.000 \\
College & -0.164 & 0.005 & -0.126 & 0.027 \\
Status & 0.119 & 0.044 & 0.124 & 0.031 \\
\hline
\end{tabular}

Note. Model 1: $R^{2}=0.075$, adjusted $R^{2}=0.071, F=15.929, p$-value = 0.000;

Model 2: $R^{2}=0.074$, adjusted $R^{2}=0.070, F=15.737, p$-value $=0.000$ 
The remaining variations in students' academic performance might be explained by other factors not investigated in this study. This can be observed in figures 3 and 4, which, since the lines in both figures deviate from the diagonals, indicate unexplained variance in the models.

\section{Figure 3}

Normal Probability Plot of Regression Standardized Residual. The figure illustrates GPA as dependent variable as mentioned in Model 1 (F2F Learning)

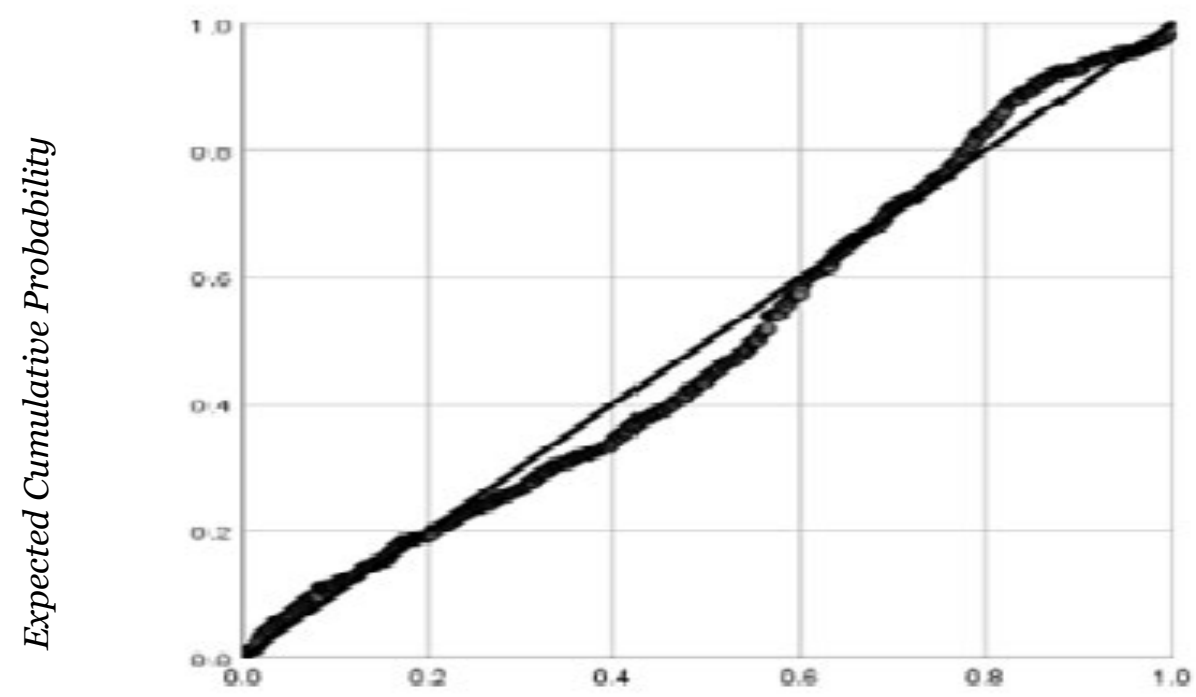

Observed Cumulative Probability

Note. $\mathrm{GPA}=$ grade point average; $\mathrm{F} 2 \mathrm{~F}=$ face to face learning. 


\section{Figure 4}

Normal Probability Plot for Variable GPA in Model 2 (DL)

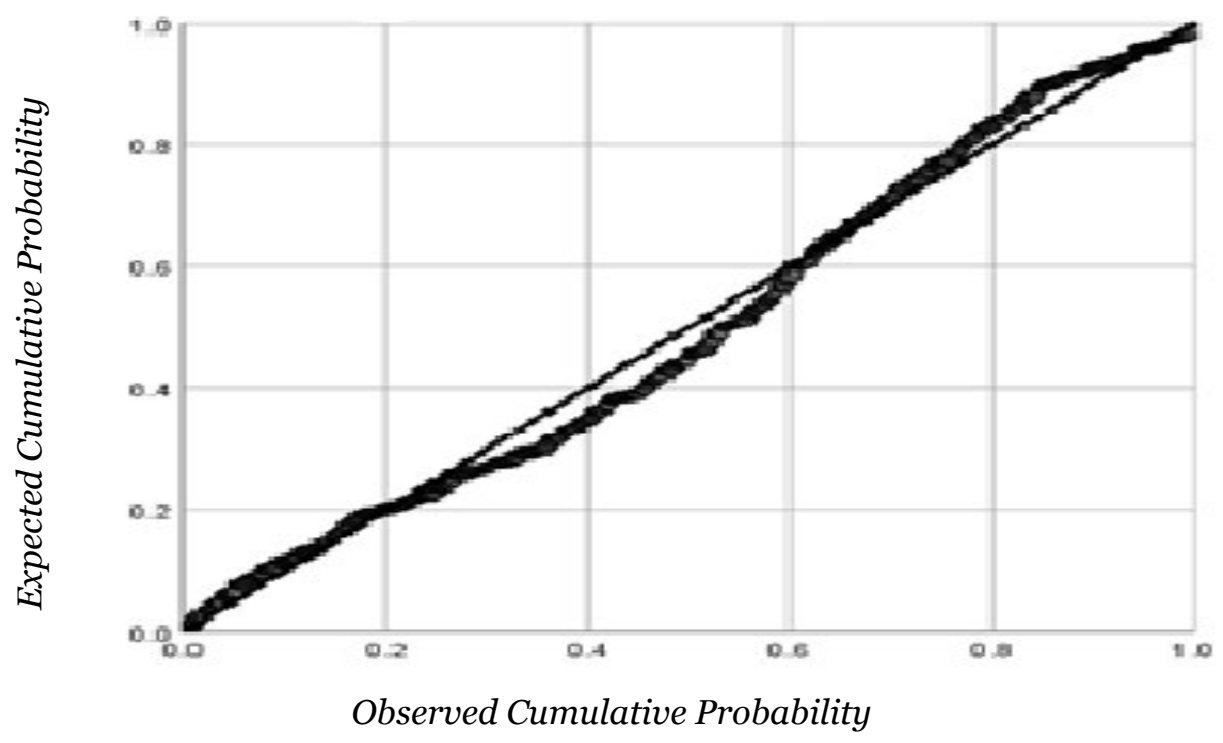

Note. $\mathrm{GPA}=$ grade point average; $\mathrm{DL}=$ distance learning.

\section{Discussion}

This study reports the impact of demographic characteristics on students' academic performance in F2F learning and DL. The results indicate that in terms of grade categories such A, B+, and B, students demonstrated better academic performance in DL than in F2F learning. Similarly, findings reveal a significant difference between F2F learning and DL for both SGPA and overall GPA. The mean score analysis of these differences shows better academic performance in DL than in F2F learning. The findings support the hypotheses and suggest a positive impact of DL on students' academic performance. These differences could be related to the use of innovative technologies and digital resources in DL. DL technologies and tools serve as vehicles and contribute to students' academic performance (Haddad et al., 2014; Cheng et al., 2017). According to Rajadurai et al. (2018), DL technologies, the quality and effectiveness of courses, and Internet efficacy are among the factors that can have a positive impact on students' performance.

These differences could also be related to teaching style. As highlighted by Natarajan (2005), innovative teaching methods used in DL help sustain student's interest and make the learning process more productive and interesting. DL provides many opportunities to students, including unlimited access to learning materials such recorded lectures, networking with people from different geographical locations and different cultures, convenience in terms of timing, actual duration, concentration, transportation and 
payment, and objectivity better achieved as compared to F2F learning (Koutsoupidou, 2014). These advantages may have a positive impact on students' academic performance in DL.

Another possibility for the difference shown in the research is academic dishonesty. Despite the advancement of educational technologies in preventing academic dishonesty in online education, students cheat and plagiarize in DL more frequently than they do in F2F learning. Prior studies have reported students' dishonesty in DL (Jocoy \& DiBiase, 2006; Michael \& Williams, 2013). Recent research by Lucky et al. (2019) found that the incidence of cheating among students of DL was 12 times higher compared to students of F2F learning. Similarly, a report by Chirumamilla et al. (2020) showed that students perceived cheating to be much easier in online examinations than in physical classroom examinations. We believe that the evaluation of students' academic performance in DL should consider academic dishonesty (Lucky et al., 2019).

Meanwhile, the findings of the study revealed the impact of demographic characteristics on academic performance. Accordingly, the results supported the theory proposed by Tinto (1975), the stated hypotheses, and the proposed models. Further analysis indicated that gender, college, and status of student explained at least $7.4 \%$ of the variation in academic performance in F2F learning and DL. Certainly, learners are different, unique, and not necessarily equal in intellectual abilities, skills, and experiences (Halpern et al., 2007; Hedges \& Friedman, 1993). Accordingly, such factors could have a significant positive influence on their academic performance. Likewise, different colleges have different characteristics that could have a positive impact on students' academic performance. These include knowledge and experience of faculty members, teaching methods and approaches, and provision of needed learning and teaching materials and equipment (Arora \& Singh, 2017). Similarly, concerning students' status, senior students show better academic performance compared to junior students. This is because senior students have more knowledge, skills, and experience in the higher education environment as compared to junior students (Hassanbeigi et al., 2011).

\section{Conclusion}

The spread of COVID-19 has created an opportunity for many educational institutions to implement DL for the first time. In implementing DL, these institutions have been able to successfully continue to provide educational resources and services to students, secure income and revenues for the institution, and contribute to the control and prevention of coronavirus pandemic in society. At AAU, the experience has been remarkable, particularly in academic performance. Despite the pandemic crisis, students achieved better academic performance in DL than in F2F learning. The implementation of DL resulted in a smaller number of weak students and an increase in the number of students with higher GPAs. However, these results are not in isolation from the impact of gender, college, and status of students. The three demographic characteristics have demonstrated a significant impact on students' academic performance in both F2F learning and DL. Non-DL institutions should continue offering DL programs side-by-side with F2F learning programs. This will attract more students and prepare for any other circumstances that might prevent the provision of F2F learning. Future researchers may wish to explore the impact of other demographic characteristics in assessing students' academic performance in both F2F learning and DL. 


\section{References}

Alghamdi, A., Karpinski, A. C., Lepp, A., \& Barkley, J. (2020). Online and face-to-face classroom multitasking and academic performance: Moderated mediation with self-efficacy for selfregulated learning and gender. Computers in Human Behavior, 102, 214-222. https://doi.org/10.1016/j.chb.2019.08.018

Al-Mously, N., Salem, R., \& Al-Hamdan, N. (2013). The impact of gender and English language on the academic performance of students: An experience from new Saudi medical school. Journal of Contemporary Medical Education, 1(3), 170-176. https://www.jcmedu.org/jcmedu-articles/theimpact-of-gender-and-english-language-on-the-academic-performance-of-students-anexperience-from-new-saudi-medical-s.pdf

Amparo, A. R., Smith, G., \& Friedman, A. (2018). Gender and persistent grade performance differences between online and face to face undergraduate classes. In T. Bastiaens, J. Van Braak, M. Brown, L. Cantoni, M. Castro, R. Christensen, G. Davidson-Shivers, K. DePryck, M. Ebner, M. Fominykh, C. Fulford, S. Hatzipanagos, G. Knezek, K. Kreijns, G. Marks, E. Sointu, E. Korsgaard Sorensen, J. Viteli, J. Voogt ... O. Zawacki-Richter (Eds.), Proceedings of EdMedia: World Conference on Educational Media and Technology (Vol. 2018, pp. 1935-1939). Association for the Advancement of Computing in Education (AACE). https://www.learntechlib.org/primary/p/184430/

Amro, H. J., Mundy, M.-A., \& Kupczynski, L. (2015). The effects of age and gender on student achievement in face-to-face and online college algebra classes. Research in Higher Education Journal, 27, 1-22. http://www.aabri.com/manuscripts/142077.pdf

Andreou, E., Vlachos, F., \& Andreou, G. (2007). Educational research approaches to studying among Greek university students: The impact of gender, age, academic discipline and handedness. Educational Research, 48(3), 301-311. https://doi.org/10.1080/00131880600992363

Arora, N., \& Singh, N. (2017). Factors affecting the academic performance of college students. IManager's Journal of Educational Technology, 14(1), 47-53. https://doi.org/10.26634/jet.14.1.13586

Ati, M., \& Guessoum, N. (2010). E-learning in the United Arab Emirates. In U. Demiray (Ed.), E-learning practices. Cases on challenges facing e-learning and national development: Institutional studies and practices (Vol. 2, pp. 1009-1028). Anadolu University. https://www.researchgate.net/publication/233428047 ELearning in the United Arab Emirates

Bernard, R. M., Abrami, P. C., Lou, Y., Borokhovski, E., Wade, A., Wozney, L., Wallet, P. A., Fiset, M., \& Huang, B. (2004). How does distance education compare with classroom instruction? A metaanalysis of the empirical literature. Review of Educational Research, 74(3), 379-439. https://doi.org/10.3102/00346543074003379 
Brubacher, M. R., \& Silinda, F. T. (2019). Enjoyment and not competence predicts academic persistence for distance education students. International Review of Research in Open and Distributed Learning, 2O(3), 165-179. https://doi.org/10.19173/irrodl.v20i4.4325

Cheawjindakarn, B., Suwannatthachote, P., \& Theeraroungchaisri, A. (2012). Critical success factors for online distance learning in higher education: A review of the literature. Creative Education, o3(8B), 61-66. https://doi.org/10.4236/ce.2012.38bo14

Cheng, F.-F., Chiu, C.-C., Wu, C.-S., \& Tsaih, D.-C. (2017). The influence of learning style on satisfaction and learning effectiveness in the asynchronous web-based learning system. Library Hi Tech, 35(4), 473-489. https://doi.org/10.1108/LHT-12-2016-0151

Chirumamilla, A., Sindre, G., \& Nguyen-Duc, A. (2020). Cheating in e-exams and paper exams: The perceptions of engineering students and teachers in Norway. Assessment and Evaluation in Higher Education, 45(7), 940-957. https://doi.org/10.1080/02602938.2020.1719975

Christmann, E. P. (2017). A comparison of the achievement of statistics students enrolled in online and face-to-face settings. E-Learning and Digital Media, 14(6), 323-330. https://doi.org/10.1177/2042753017752925

D’Abundo, M. L., \& Sidman, C. (2018). Integrating web-based technologies into the education and training of health professionals. In M. Khosrow-Pour, D.B.A. (Ed.), Encyclopedia of information science and technology (4th ed., pp. 5820-5828). IGI Global. https://doi.org/10.4018/978-15225-2255-3.ch506

Duffy, T., Gilbert, I., Kennedy, D., \& Kwong, P. W. (2002). Comparing distance education and conventional education: Observations from a comparative study of post-registration nurses. Research in Learning Technology, 1O(1), 70-82. https://doi.org/10.1080/0968776020100110

Elfaki, N. K., Abdulraheem, I., \& Abdulrahim, R. (2019). Impact of e-learning vs traditional learning on students performance and attitude. International Journal of Medical Research \& Health Sciences, 8(10), 76-82. https://www.ijmrhs.com/medical-research/impact-of-elearning-vstraditional-learning-on-students-performance-and-attitude.pdf

Fadda, A. (2019). The relationship between self-regulations and online learning in an ESL blended learning context. English Language Teaching, 12(6), 87-93. https://doi.org/10.5539/elt.v12n6p87

Ferguson, J., \& Tryjankowski, A. M. (2009). Online versus face-to-face learning: Looking at modes of instruction in master's-level courses. Journal of Further and Higher Education, 33(3), 219-228. https://doi.org/10.1080/03098770903026149

Haddad, M. E. O., Ferreira, N. S. C., \& Faria, A. A. (2014). The use of educational technologies in distance education: Enabling the appropriation of teaching and learning process. Open Journal of Social Sciences, 2(1), 54-58. https://doi.org/10.4236/iss.2014.21006 
Halpern, D. F., Benbow, C. P., Geary, D. C., Gur, R. C., Hyde, J. S., \& Gernsbacher, M. A. (2007). The science of sex differences in science and mathematics. Psychological Science in the Public Interest, 8(1), 1-51. https://doi.org/10.1111/j.1529-1006.2007.00032.x

Hassanbeigi, A., Askari, J., Nakhjavani, M., Shirkhoda, S., Barzegar, K., Mozayyan, M. R., \& Fallahzadeh, H. (2011). The relationship between study skills and academic performance of university students. Procedia-Social and Behavioral Sciences, 30, 1416-1424. https://doi.org/10.1016/j.sbspro.2011.10.276

Hedges, L. V., \& Friedman, L. (1993). Gender differences in variability in intellectual abilities: A reanalysis of Feingold's results. Review of Educational Research, 63(1), 94. https://doi.org/10.2307/1170561

Ibrahim, M., Rwegasira, K. S. P., \& Taher, A. (2007). Institutional factors affecting students' intentions to withdraw from distance learning programs in the Kingdom of Saudi Arabia the case of the Arab Open University (AOU). Online Journal of Distance Learning Administration, 1O(1), 1-19. https://www.westga.edu/ distance/ojdla/spring101/ibrahim101.htm

Ismail, A. O. A., Mahmood, A. K., \& Abdelmaboud, A. (2018). Factors influencing academic performance of students in blended and traditional domains. International Journal of Emerging Technologies in Learning, 13(2), 170-187. https://doi.org/10.3991/ijet.v13io2.8031

Jahng, N., Krug, D., \& Zhang, Z. (2007). Student achievement in online distance education compared to face-to-face education. European Journal of Open, Distance and E-Learning, 1O(1), 1-16. https://core.ac.uk/download/pdf/24065525.pdf

Jocoy, C., \& DiBiase, D. (2006). Plagiarism by adult learners online: A case study in detection and remediation. The International Review of Research in Open and Distributed Learning, 7(1), 1-16. https://doi.org/10.19173/irrodl.v7i1.242

Kamalluarifin, W.S.F.W., Aniza, F.N.F.M., Jayabalan, H., Saufi, M.L.H.M., Bakar, N.A.A., \& Karib, S.H.F. (2018). Blended learning: Satisfaction among accounting students in UNITEN KSHAS. Global Business \& Management Research, 10(3), 547-557. https://drive.google.com/file/d/1yoHxeqOrcxU8otrtUChK SEiPf2ErH /view

Koutsoupidou, T. (2014). Online distance learning and music training: Benefits, drawbacks and challenges. Open Learning: The Journal of Open, Distance and E-Learning, 29(3), 243-255. https://doi.org/10.1080/02680513.2015.1011112

Lavine, J., \& Croome, R. (2018). United Arab Emirates.I In A.S. Weber \& S. Hamlaoui (Eds.), E-learning in the Middle East and North Africa (MENA) region (pp. 433-45o). Springer.

Logan, J. W., Lundberg, O. H., Roth, L., \& Walsh, K. R. (2017). The effect of individual motivation and cognitive ability on student performance outcomes in a distance education environment. Journal 
of Learning in Higher Education, 13(1), 83-91.

https://jwpress.com/Journals/JLHE/BackIssues/JLHE-Spring-2017.pdf

Lucky, A., Branham, M., \& Atchison, R. (2019). Collection-based education by distance and face to face: Learning outcomes and academic dishonesty. Journal of Science Education and Technology, 28, 414-428. https://doi.org/10.1007/s10956-019-9770-8

Michael, T.B., \& Williams, M.A. (2013). Student equity: Discouraging cheating in online courses. Administrative Issues Journal: Education, Practice, and Research, 3(2), 30-41. https://dc.swosu.edu/aij/vol3/iss2/6

Natarajan, M. (2005). Innovative teaching techniques in physical education. Communication of the IIMA, 5(4), 73-80. https://scholarworks.lib.csusb.edu/ciima/vol5/iss4/10/

Nortvig, A.-M., Petersen, A. K., \& Balle, S. H. (2018). A literature review of the factors influencing elearning and blended learning in relation to learning outcome, student satisfaction and engagement. The Electronic Journal of E-Learning, 16(1), 46-55. http://www.ejel.org/volume16/issue1

Ortega-Maldonado, A., Llorens, S., Acosta, H., \& Coo, C. (2017). Face-to-face vs on-line: An analysis of profile, learning, performance and satisfaction among post graduate students. Universal Journal of Educational Research, 5(10), 1701-1706. https://doi.org/10.13189/ujer.2017.051005

Paul, J., \& Jefferson, F. (2019). A comparative analysis of student performance in an online vs. face-toface environmental science course from 2009 to 2016. Frontiers in Computer Science, 1(article 7), 1-9. https://doi.org/10.3389/fcomp.2019.00007

Rajadurai, J., Alias, N., Jaaffar, A. H., \& Hanafi, W. N. W. (2018). Learners' satisfaction and academic performance in open and distance learning (ODL) universities in Malaysia. Global Business and Management Research, 1O(3), 511-523. http://gbmrjournal.com/vol1ono3.htm

Shachar, M., \& Neumann, Y. (2010). Twenty years of research on the academic performance differences between traditional and distance learning: Summative meta-analysis and trend. MERLOT Journal of Online Learning and Teaching, 6(2), 318-334. http://jolt.merlot.org/vol6no2/shachar 0610.pdf

Smith, N. V. (2013). Face-to-face vs. blended learning: Effects on secondary students' perceptions and performance. Procedia-Social and Behavioral Sciences, 89, 79-83. https://doi.org/10.1016/j.sbspro.2013.08.813

Stark, E. (2019). Examining the role of motivation and learning strategies in the success of online versus face-to-face students. Online Learning Journal, 23(3), 234-251. https://doi.org/10.24059/olj.v23i3.1556

Stegers-Jager, K. M., Savas, M., van der Waal, J., van Rossum, E. F. C., \& Woltman, A. M. (2020). Gender- 
specific effects of raising Year-1 standards on medical students' academic performance and stress levels. Medical Education, 54(6), 538-546. https://doi.org/10.1111/medu.14068

Tamim, R. M., Bernard, R. M., Borokhovski, E., Abrami, P. C., \& Schmid, R. F. (2011). What forty years of research says about the impact of technology on learning: A second-order meta-analysis and validation study. Review of Educational Research, 81(1), 4-28.

https://doi.org/10.3102/0034654310393361

Tinto, V. (1975). Dropout from higher education: A theoretical synthesis of recent research. Review of Educational Research, 45(1), 89-125. https://doi.org/10.3102/00346543045001089

United Arab Emirates, the Ministry of Education (2020, March 4). Education ministry announces early 4-week spring vacation, starting Sunday [Press release]. https://www.moe.gov.ae/en/mediacenter/news/pages/springvacation.aspx

United Arab Emirates' Government Portal. (2020, August 25). School break amid COVID-19. https://u.ae/en/information-and-services/education/school-break-amid-covid19

Urtel, M. G. (2008). Assessing academic performance between traditional and distance education course formats. Educational Technology and Society, 11(1), 322-330. http://www.jstor.org/stable/jeductechsoci.11.1.322

Zhao, L., \& Abuizam, R. (2015). The impact of adaptive learning in an introductory management distance education course: An empirical comparison. Academy of Educational Leadership Journal, 19(3), 359. https://www.questia.com/library/journal/1P3-3966658211/the-impact-of-adaptivelearning-in-an-introductory

\section{Athabasca University}

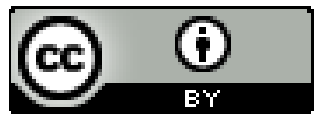

